\title{
- A stratégiai megközelítés fejlesztése a helyreállítási eszközt és az ellenállási alapot igénybe vevő közlekedési infrastruktúra tervezésben
}

\section{Tánczos Lászlóné ${ }^{1}$}

${ }^{1}$ Budapesti Műszaki és Gazdaságtudományi Egyetem, Közlekedésüzemi és Közlekedésgazdasági Tanszék

E-mail: tanczos.laszlone@edu.bme.hu

DOI: $10.36246 /$ UL.2021.1.05

\section{KIVONAT}

A közel jövőben megnyíló és hazánk számára is jelentős volumenben rendelkezésre álló két pénzügyi forrás a gazdaság megújítására szolgáló helyreállítási eszköz és a klímaváltozás kedvezőtlen hatásainak mérséklésre fordítandó, egyebek mellett a közlekedési infrastruktúra környezetbarát kialakítását célzó ellenállási alap. Az Európai Bizottság mellett az OECD-be integrált, 62 tagországot magába foglaló nemzetközi kormányközi közlekedési szervezet, az International Transport Forum (ITF) is kiemelt figyelmet fordít a fenti célok érdekében létesített financiális alapok jól átgondolt és ésszerü, stratégiai szemléletet tükröző fejlesztésekre történő igénybevételére és transzparens felhasználására. Az ITF, melynek hazánk 1991 óta tagja, 2021 márciusában száz oldalas jelentést tett közzé, amelyben a vonatkozó közlekedéspolitikai kérdések előzetes globális vitájának eredményeit foglalta össze. Tekintettel a téma hazai aktualitására, jelen cikk - kiemelve az infrastruktúra tervezés stratégiai megközelítésének főbb szempontjait és összefoglalva legfontosabb ajánlásait - rövid áttekintést ad az ITF tanulmányáról [1].

Kulcsszavak: stratégiai szempontú fejlesztés, átláthatóság, szektorokon átívelő, megújítási alap, rugalmas közlekedési infrastruktúra

\section{ABSTRACT}

Two funds in significant volume will be opened and available for our country, too in the near future, the recovery fund to renew the economy and the funded capital to improve the resilience of transport infrastructure against the impacts of climate change. Besides the European Commission the intergovernmental transport organization, the International Transport Forum (ITF) at OECD, comprising 62 member countries, pays also great attention to the rational utilization of these financial funds established with the above mentioned objectives for infrastructure development reflecting strategic approach and providing transparency. In March of this year ITF including Hungary as member country since 1991, published a report in hundred pages which summed up the results of a previous global discussion of related transport policy questions. With consideration to the actuality of the topic this paper gives a short overview on the study highlighting the main aspects of strategic approach to transport infrastructure planning and itemizes its important proposals.

Keywords: developing strategic approaches, transparency, cross-sectorial, recovery fund, resilient transport infrastructure

\section{Dr. Tánczos Lászlóné}


Tánczos Lászlóné, az MTA doktora, a BME Közlekedésüzemi és Közlekedésgazdasági Tanszék emerita professzora. Fö kutatási területe: közlekedési externáliák, közlekedési infrastruktúra, optimalizálási alkalmazások. Publikációs lista: https://mta.hu/koztestuleti tagok?PersonId=7217)

\section{BeVEzetés}

Az infrastruktúra biztosítja a nemzetgazdaság müködéséhez elengedhetetlen és az emberek széles értelemben vett életminőségének fenntartásához szükséges fizikai és digitális kapcsolatokat. Ezért az abba történő beruházási döntések megalapozott tervezése az erőforrások pazarlásának, de a környezeti károk elkerülése szempontjából is kritikus jelentőségü. A közlekedési infrastruktúra hosszú élettartamú fejlesztési ütemtervei miatt az előnyök - a rövid távú politikai és választási ciklusokkal szemben - csak jóval a költségek keletkezése után érezhetők. A stratégiai megközelítésű döntéshozatal viszont a következő évtizedek alatt fokozott elönyökkel járhat.

$\mathrm{Az}$ infrastruktúra iránti igények/szükségletek (kereslet) és az infrastruktúra szolgáltatások teljesítményének (kínálat) mérésére alkalmas, általánosan elfogadott mutatók hiánya nehezíti az országok és szektorok közötti értelmes összehasonlításokat. A technológiai és demográfiai változások vagy a jelenlegi járvány által okozott - alapvető változásokkal járó, jelentős hatást kiváltó - események előfordulása esetén minden infrastruktúra tervnek hatékonyan kell kezelnie a bizonytalanságot.

A szektorokon belüli és a különböző szektorok közötti egyre növekvő interakciók - különösen az elektromos közúti közlekedés nagy arányú és gyors terjedése - felgyorsítják és a többszörös hálózati beágyazódással összefüggésben egyre bonyolultabbá teszik a fejlesztési ütemterveket. Ezen interakciók miatt egyre fontosabbá válik az infrastruktúra tervezés hosszú távú és ágazatokon átívelő stratégiai vezérlése, menedzselése.

Mindezen okok miatt létfontosságú az infrastrukturális beruházási stratégiák kidolgozásának kérdése, amely egyúttal hatalmas kihívást is jelent. Az elmúlt években számos új megközelítés történt, melynek célja a jobb fókuszálás a jövőbeni igények kielégítésére és kifinomultabb stratégiai tervek készítése a fejlesztések megvalósításához. Ide sorolható az új, innovatív módszerek kidolgozása és független tanácsadó testületek létrehozása a kormány és a döntéshozók támogatására. Mind ezek mellett egyre nagyobb hangsúlyt fektetnek a nagy infrastruktúra projektek tényleges teljesítményének mérésére is.

A világ szinte minden országában stratégiákat dolgoznak ki a covid-19 járványból történő kilábalásra, melyben az infrastruktúra beruházások központi szerepet játszanak. Fiskális ösztönzőket biztosítanak a munkahelyek támogatásához, a megújulástól függő hálózatok létrehozásához, megerősítéséhez, lehetővé téve egyúttal az alacsonyabb széndioxid-kibocsátású, fenntarthatóbb gazdasági modellre való áttérést. Ezzel biztosítható, hogy a beruházásokra valóban ott kerüljön sor, ahol azokra a legnagyobb szükség van.

A jelentés áttekintést ad ezekről a fejleményekről, vázolja azok hatásait és eredményeit, továbbá ajánlásokat ad az infrastruktúra tervezésének, a döntések minőségének, következetességének és koherenciájának javítására.

\section{A STRATÉGIAI MEGKÖZELÍTÉS ÁLTALÁNOS JELLEMZŐI ÉS MÓDSZERTANI VONATKOZÁSAI}

A stratégiai tervezés olyan, viszonylag gyakran használt szakpolitikai eszköz, amelynek célirányos alkalmazása egyre inkább terjed. Általános tartalmi elemei: a projektek azonosítása, értékelése és kiválogatása.

A stratégiai tervek jellege és hatóköre nagymértékben különbözik egymástól; némelyik ágazati alapú, mások regionális szempontúak és előfordul több szakterületet érintő ágazatközi stratégia is, illetve alkalmaznak olyan stratégiai tervezést is, amely akár hosszabb távú kormányzati perspektívát is magába foglal. Némelyik stratégiai terv csupán tág irányvonalak és/vagy célok meghatározására korlátozódik, míg mások egyedi projekteket határoznak meg. Általános jellemzőjük, hogy rendszerint nagyszabásúak 
és/vagy átalakító hatásúak. A stratégiai tervek teszik lehetővé az összehangolt döntéshozatalt, amely nemcsak a projektek közötti szinergiákat veszi figyelembe, de egyidejüleg tekint az infrastruktúra szolgáltatások iránti keresletre és a kínálatra, miközben mérlegeli a különbözö ágazatok versengő igényeit és lehetővé teszi a beruházási döntések nemzeti prioritásokhoz való igazodását is.

Nyilvánvaló összefüggés áll fent a stratégiai tervezés szükségességének felismerése és független infrastruktúra tanácsadó testületek létrehozása között. Mivel a legtöbb országban csak a közel múltban került sor ezeknek a testületeknek a felállítására, ezért a döntéshozatal javításának hatékonyságáról, azaz e testületek müködésének eredményességéről kialakítható gyakorlati tapasztalatok még csak korlátozottan állnak rendelkezésre. Bár a testületekre háruló felelősség széles skálája és egymástól jelentősen eltérő tartalma ugyancsak bonyolítja ítéleteik konszenzuson alapuló kialakítását, mégis úgy tünik, hogy az infrastruktúra szükségletekkel és prioritásokkal összefüggő projektek azonosításával kapcsolatban meghozott független szakértői tanácsok általában javítják a döntéshozatal információs bázisát, ami fokozza az átláthatóságot és az elszámoltathatóságot.

A projektek értékelési módszertanának alkalmazása a legtöbb országban meghatározott eljárási rend és előre rögzített követelmények szerint történik, amelyek között a költség-haszon elemzés (CBA) gyakorlatilag minden esetben központi szerepet játszik. Sok ország szerint a javasolt projekteknek meg kell felelniük bizonyos kritériumoknak (pl. pozitív nettó jelenértékkel (NPV) és meghatározott küszöbérték feletti BCR (benefit/cost ratio; haszon/költség arány) mutatóval kell rendelkezniük ahhoz, hogy jóváhagyásra jogosultak legyenek. Mások szerint a CBA csak egy a számos elvégzett elemzés közül, ezért a pozitív NPV nem feltétlenül szükséges vagy elegendő egy projekt kiválasztásához. A CBA hatókörének különbségei magyarázhatják e látszólagos különbségek egy részét. Egyes országok szélesebb hatástartományra kidolgozott CBA-t fogadnak el olyan közvetett értékelési technikák használatát követelve, amelyek számos nem piaci előny és költség számszerüsítését teszik lehetővé.

A nagyszabású infrastrukturális projektek értékelése - különösen, ha az az un. tovagyürüző (másodlagos vagy közvetett) hatások számbavételére is kiterjed - egyre szélesebb körü gazdasági előnyöket (Wider Economic Benefits, WEB) tartalmaz. A WEB-es értékelés végrehajtása nagyon adatés erőforrás igényes. Ez azt jelenti, hogy a CBA mikrogazdasági szemléletü elemzéséhez hozzáadódik a makrogazdasági elemzés egy eleme. Ennek megfelelően - az összes leginkább átalakító hatású projekt kivételével - a szélesebb gazdasági előnyök (WEB) valószínüleg csak 10-30\%-kal egészítik ki a hagyományos haszonbecsléseket. Ezért a WEB-es értékelést általában azokra a projektekre tartják fenn, amelyek várhatóan nagy hatással lesznek a munkaeröpiacokra. Bár a legtöbb WEB becslést jelentős bizonytalanság övezi, mégis a WEB elemzés segíthet tisztább képet adni a projekt kedvezményezettjeiről. Fontos elvárás azonban, hogy a WEB elemzés alkalmazásakor ne kerüljön sor bizonyos előnyök kettős számbavételére.

Számos infrastruktúra létesítmény egyidejűleg többféle gazdasági és/vagy társadalmi cél különböző arányú kiszolgálásához járul hozzá. A megosztott infrastruktúra gyakorlatának terjedése mind a méretek/kiterjedtség növekedése, mind az ellátott feladatok/funkciók/területek összetételének bővülése/változása tekintetében eredményezhet hatékonyság javulást. A térségek, régiók és országok közötti kölcsönös gazdasági érdekeltség elmélyítése ugyancsak hozzájárul közös, új hozamok létrehozásához. Az infrastruktúra megosztott üzemeltetése ugyanakkor azonban megköveteli a józan intézményi architektúrát, a világos politikai célokat és a kölcsönösen elfogadott felelőségmegosztást.

A stratégiai szemléletü infrastruktúra tervezés magában foglalja a kiadások ésszerü allokációját az új infrastruktúra projektekre szánt és a már meglévő létesítmények fenntartására/korszerüsítésére fordított kiadások között is. Ez azt jelenti, hogy a stratégiai szemléletü infrastruktúra tervezőknek célirányosan és eredményesen tárgyalniuk kell nemcsak a meglévő eszközök kezelőivel/fenntartóival/finanszírozóival, de az új projektek kiválasztásához és fejlesztéséhez is meg kell találniuk a megfelelő anyagi eszközöket. Ily módon a hatékony vagyongazdálkodással összefüggő több-körös egyeztetés a vonatkozó „stakeholderek”-kel ugyancsak elengedhetetlen feltétele az eredményességnek, de e tevékenység magas szintü, professzionális művelése jelentősen csökkenti az infrastruktúra teljes élet ciklus költségét. 


\section{A STRATÉGIAI SZEMLÉLETVÁLTÁS LEGFONTOSABB SZEMPONTJAINAK ÉRVÉNYESÍTÉSÉRE VONATKOZÓ AJÁNLÁSOK}

A kormányoknak az infrastruktúra tervezésére stratégiai megközelítést kell alkalmazniuk. Ezt világosan, egy határozott és részletes, időszakosan korszerüsített stratégiai tervvel kell kommunikálni.

Ezeket a terveket minden fö fizikai infrastruktúra szektorra ki kell terjeszteni és az infrastruktúra iránti kereslet és kínálat alakulását figyelembe vevő, elfogadható forgatókönyveket kell kidolgozni. A terveknek az infrastruktúra fejlesztésére és üzemeltetésére egyaránt vonatkozó világos javaslatokat kell megfogalmazniuk, abból a célból, hogy informálják a kormányt a beruházási döntésekről és felállítsák az alkalmazandó „policy”-k (politikai célok megvalósítására szolgáló szabályozási beavatkozások, eszközök) olyan keretrendszerét, amely alátámasztja a szabályozási döntéseket és a magán szféra beruházásait.

A stratégiai infrastruktúra terveket, legalább is széles értelemben véve, össze kell kapcsolni az arra a célra azonosított/megnyitott konkrét költségvetési finanszírozási forrásokkal.

Ehhez rendelkezni kell a stratégiai infrastruktúra tervek és az egyes projektek kiválasztási folyamata közötti világos kapcsolatok ismeretével.

A kormányoknak mérlegelniük kell, érdemes-e független infrastruktúra fejlesztő tanácsadó testületet felállítani ahhoz, hogy biztosítható legyen az átlátható szakértői tanácsadás a hosszútávú, szektorokon átívelő infrastruktúra stratégiához, a tervek és a „policy”-k kifejlesztéséhez épp úgy, mint a közép- és hosszú távú beruházások közötti prioritások eldöntéséhez.

Mára már nyilvánvalóvá vált, hogy ezek a testületek olyan alacsony költségü és hatékony megoldási lehetőséget jelentenek a fenti problémák megoldására, amelyek javítják és jól kiegészítik a meglévő folyamatokat. Független tanácsadó testületek törvényes létesítése egyrész erősíti azt a lehetőséget, hogy a testület tagjai képesek legyenek becsületes, félelem nélküli vélemény alkotásra, másrészt létrehívásuk módja és az így érvényesülő státuszuk az érintettek (stakeholder-ek) széles körében jelentősen fokozza hitelességüket is.

A független testületek létrehozásával kapcsolatos előkészületek tartalmazzák az OECD által meghatározott kulcsfontosságú vezérlő elveket, amelyek a szabályozók kormányzására vonatkoznak.

Ezek az elvek elöírják, hogy a tanácsadó testületeknek nyilvánosságra kell hozniuk a kormány részére tett tanácsaikat, a kormányoktól pedig meg kell követelni az ezekre a tanácsokra vonatkozó, belátható időn belüli válaszadást.

Az infrastruktúra projektek értékelésének, amennyire az lehetséges, átlátható és konzisztens módszertanon kell alapulnia.

$\mathrm{Az}$ értékelésnek ki kell térnie a javasolt projekt minden lényeges hatására, beleértve a fenntarthatóságot, az egészséget és a biztonságot, valamint a disztribúciós vonatkozásokat is. Ezeket figyelembe véve, a kiterjesztett CBA képes hozzájárulást biztosítani a leginkább integrált elemzéshez, amely segíti a beruházási lehetőségek közötti összehasonlítást. A legnagyobb projektekre fókuszálva, továbbá a hagyományos közlekedési projektekhez képest szélesebb célrendszert megvalósító beruházásoknál szelektív módon célszerü alkalmazni a szélesebb értelemben vett előnyök (WEB) elemzésekbe történő bevonását. A WEB becsléseknek a kulcsfontosságú bizonytalanságokat kell megvilágítaniuk és ahol az megfelel, forgatókönyv elemzéseket kell tartalmazniuk. A projekt értékelésnek el kell különítenie a WEB-et a többi elemzéstől, hogy világossá váljék a WEB-ek teljes eredményre gyakorolt hatása.

Az OECD/ITF áttekintést köteles készíteni a kormányzat és a magán szféra COVID-19 járványra adott infrastruktúra vonatkozású válaszairól.

Az elkészítendő szemlének át kell tekintenie, hogy a járvány következményeként valószínüsíthetően hogyan változik meg (különösen a közlekedési és a telekommunikációs) infrastruktúra iránti igény. Azt 
is szükséges értékelni, hogy a kormány és a magán infrastruktúra biztosítók vajon változtatni fogják-e és milyen módon stratégiai terveiket és az értékelési eljárást, valamint a projektek prioritásait.

Egy formális „policy”-keretrendszernek kell útmutatást adnia a fö infrastruktúra eszközök/vagyonok felügyeletével/kezelésével kapcsolatos döntésekhez

A cél a hatékony eszköz kihasználás biztosítsa, a maximális elérhetőség és teljesítmény, valamint a teljes életciklus költség minimalizálása kell legyen. Ezt mértékadó teljesítmény-normák felállításával, a fenntartások és felújítások optimális ütemezésével kapcsolatos ösztönzőkkel kell elérni. Ehhez az eszköz-tulajdon és az eszköz-gazdálkodás/-menedzsment szétválasztására lesz szükség annak érdekében, hogy megteremtsék a világos pénzügyi elszámoltathatóság és ösztönzés feltételeit. Ugyancsak szükség lesz egy megfelelő (lehetőleg szektorokon átívelö) szabályozó rendszer létesítésére, ahol a megvalósítható verseny hiányzik.

A kormányoknak át kell tekintenie az infrastruktúra szabályozás keretrendszereit

$\mathrm{Az}$ áttekintésnek keresnie kell a lehetőségeket arra vonatkozóan, hogy minél több területen támogassák a szektorokon átívelő (cross-sectorial) tervezés integrált megközelítését, annak érdekében, hogy a nem kívánatos következmények elkerülhetök legyenek.

Minden nagy projektre végre kell hajtani az ex post (utólagos) értékelést

Erre a célra a szabványos CBA érékelés keretrendszerét és módszereit kell használni. Metaelemzéseket kell elvégezni a jövő infrastruktúra -,,policy”-jáihoz szükséges minél jobb tájékoztatás érdekében.

Nemzeti infrastruktúra intézmények és statisztikai ügynökségek nemzetközi együttmüködésével konzisztens infrastruktúra teljesítmény mutatókat kell kidolgozni

Teljesítmény mértékek/mutatók és indikátorok segítségével feltárhatók az infrastruktúra rendszerek erősségei és gyengeségei és értékelni lehet a múltbeli beruházások hatásait. A gazdasági statisztika egyéb területein nemzetközi harmonizációval elért sikerek azt sugallják, hogy lehetőség van az infrastruktúra teljesítményének mérésére szolgáló, olyan összemérhető mutatók fejlesztésére, amelyek. alkalmasak nemzetközi összehasonlításra is. Ezek támaszthatják alá a nemzeti infrastruktúra intézmények és statisztikai ügynökségek összehasonlító tevékenységét.

Ahol határokon átívelő projekteket kívánnak megvalósítani, ott olyan speciális célú menedzsmentet kell alkalmazni, amelyben minden érintett fél képviselettel rendelkezik. A "policy" célokat és teljesítmény normákat világosan specifikálni szükséges és ki kell alakítani az irányítás, a forrásbiztosítás és az elszámoltathatóság biztosításának feltételeit.

A megosztott infrastruktúra hatékony üzemeltetése fontos kihívásokat gerjeszt, különösen ott, ahol nagyobb az együttmüködésre vállalkozó országok/régiók/térségek száma és jelentősen eltérnek egymástól a gazdasági, kulturális szokások. Ezek hatékony kezelése a világos politikai célok és elfogadott felelőség megosztás mellett megfelelő intézményi struktúra kialakítását is megköveteli.

\section{IRODALOMJEGYZÉK}

[1]: (ITF, 2021) Developing strategic approaches to infrastructure planning 